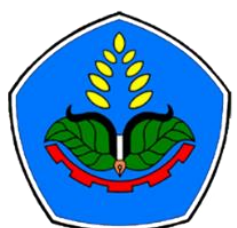

AGROPROSS

National Conference

Proceedings of Agriculture

\section{Proceedings: \\ Peran Teaching Factory Di Perguruan Tinggi Vokasi Dalam Mendukung Ketahanan Pangan Pada Era New Normal}

Tempat : Politeknik Negeri Jember

Tanggal : 8-9 Juli 2020

\section{Publisher:}

Agropross, National Conference Proceedings of Agriculture

ISBN : 978-623-94036-6-9

DOI : 10.25047/agropross.2020.9

\title{
Reduksi Amonia Oleh Kangkung Darat (Ipomea Reptans) Pada Budidaya Ikan Menggunakan Teknologi Vertiminaponik
}

\author{
Author(s): Nofi A Rokhmah ${ }^{(1)}$, Muhammad Rahman ${ }^{(2)}$, Yudi Sastro ${ }^{(3)}$ \\ (1) Balai Pengkajian Teknologi Pertanian Jakarta \\ (2) Universitas Al Azhar Indonesia \\ (3) Balai Pengkajian Teknologi Pertanian Bengkulu \\ * Corresponding author: nofianisa2012@gmail.com
}

\begin{abstract}
Vertiminaponik is one of the fish culture technologies that is integrated with aquaculture (aquaponics), assembled using water gutters as a container for plants and water tank for raising fish. Water containing leftover food and fish droppings containing ammonia has flowed to plants which have the function as a reducing agent. This study observed to determine the ability of kangkung plants to reduce ammonia in fish culture using vertiminaphonik technology. The research was carried out at the Jakarta Assessment of Agricultural Technology in February - March 2017. The experimental design was used as a randomized complete block design with three replications. Kangkung was planted using a mixture of zeolite and compost media. As comparison is an empty gutter that is not planted. The observed variables were ammonia inlet, ammonia outlet, ammonia reduction, $\mathrm{pH}$ and water temperature, and plant height. The data were analyzed using the variance and continued with LSD if there were differences. The results of the observation showed that kangkung could break down the ammonia levels contained in water from fish ponds. Kangkong did a fairly good reduction of ammonia, seen from the control comparison without plants having the smallest reduction. Statistical analysis of the average data of ammonia inlet, outlet, and ammonia reduction showed no significant difference. Vertiminaponik has a daily $\mathrm{pH}$ of 7.5 and an average temperature of $27.250 \mathrm{C}$. The kangkung height showed significantly different, in the third week the average height was $17 \mathrm{~cm}$. Vertiminaphonik becomes an aquaponic technology that is suitable for both fish and plants culture because kangkung can reduce the ammonia well.
\end{abstract}

Keyword:

Ammonia;

Fish;

Kangkung;

Vertiminaphonic;

\section{Kata Kunci:}

Amonia;

Ikan;

Kangkung;

Vertiminaponik;

\begin{abstract}
ABSTRAK
Vertiminaponik merupakan salah satu teknologi budidaya ikan yang terintegrasi dengan budidaya tanaman (akuaponik), dirakit menggunakan talang-talang air sebagai wadah tanaman dan toren air untuk memelihara ikan. Air yang berisi sisa-sisa pakan dan kotoran ikan memiliki kandungan amonia dialirkan ke tanaman yang berfungsi sebagai pereduksi. Penelitian ini bertujuan untuk mengetahui kemampuan tanaman kangkung mereduksi amonia pada budidaya ikan menggunakan teknologi vertiminaponik. Penelitian ini dilaksanakan di Balai Pengkajian Teknologi Pertanian DKI Jakarta pada bulan Februari - Maret 2017. Rancangan percobaan yang digunakan adalah rancangan acak lengkap dengan tiga ulangan. Tanaman kangkung ditanam menggunakan media campuran zeolit dan kompos. Sebagai pembanding adalah talang kosong yang tidak ditanami. Peubah yang diamati adalah amonia inlet, amonia outlet, reduksi amonia, $\mathrm{pH}$ dan suhu air, tinggi tanaman, Data dianalisis menggunakan sidik ragam dan dilanjutkan dengan LSD jika terdapat perpedaan. Hasil pengamatan menunjukkan tanaman kangkung dapat mengurai kadar amonia yang terkandung dalam air dari kolam ikan. Tanaman kangkung melakukan reduksi amonia yang cukup baik, terlihat dari pembanding kontrol tanpa tanaman memiliki reduksi yang paling kecil. Analisis statistik terhadap data rata-rata amonia intlet, outlet dan reduksinya menunjukkan tidak berbeda nyata. Vertiminaponik memiliki $\mathrm{pH}$ harian 7.5 dan rata-rata suhu $27.250 \mathrm{C}$. Tinggi tanaman kangkung menunjukkan berbeda nyata, pada pekan ke tiga rata-rata tingginya adalah $17 \mathrm{~cm}$. Vertiminaponik menjadi teknologi akuaponik yang sesuai untuk budidaya ikan sekaligus tanaman, karena tanaman yang ditanam seperti kangkung mampu mereduksi dengan baik amonia.
\end{abstract}




\section{PENDAHULUAN}

Arahan dan himbauan pemerintah pada masa pandemik covid-19 ini adalah masyarakat dapat melakukan kemandirian pangan. Pemberlakuan new normal belum dapat menjadi patokan untuk masyarakat dapat dengan bebas beraktifitas di luar rumah. Ketahanan pangan keluarga saat ini menjadi perhatian dari berbagai pihak. Pemenuhan kebutuhan pangan hendaknya dapat dilakukan sendiri dengan memanfaatkan potensi yang ada di sekitar tempat tinggal. Namun, kondisi perumahan di perkotaan yang didesain berukuran kecil dan hanya memenuhi fungsi kebutuhan hunian, menyebabkan terbatasnya lahan untuk budidaya perikanan ataupun pertanian.

Salah satu solusi untuk mengatasi keterbatasan lahan adalah dengan bioterintegrasi sistem produksi pangan dan budidaya ikan (akuaponik), terdiri dari akuakultur yang menggunakan resirkulasi tertutup dikombinasikan dengan budidaya tanaman (Estim et al. 2019). Nutrisi yang dihasilkan dari budidaya ikan digunakan untuk memenuhi kebutuhan hara tanaman. Balai Pengkajian Teknologi Pertanian DKI Jakarta memiliki tupoksi untuk melakukan pengkajian dan penelitian urban farming mengatasi keterbatasan lahan. Salah satu teknologi yang dikembangkan adalah vertiminaponik, model akuaponik menggunakan tandon air sebagai tempat budidaya ikan dan talang-talang air yang diatur pada rak besi sebagai tempat budidaya tanaman (Rokhmah et al. 2014).

Ikan lele menjadi salah satu jenis ikan tawar yang digunakan dalam budidaya vertiminaponik. Jenis ikan lele dipilih karena dapat dibudidayakan di lahan dan sumber air yang terbatas dengan padat tebar tinggi. Secara ekonomis sangat menguntungkan tidak memerlukan perawatan yang rumit, penghasil protein yang tinggi sehingga sangat baik untuk pemenuhan gizi dan harga jualnya terjangkau oleh masyarakat. Ikan lele memiliki alat pernafasan tambahan yang dapat membantu untuk memanfaatkan oksigen yang berada di udara secara langsung, sehingga lele mampu bertahan hidup pada perairan dengan kandungan oksigen rendah (Primaningtyas et al. 2015). Hal ini juga sangat bermanfaat saat listrik mati, yang menyebabkan pompa air untuk mengalirkan oksigen ke dalam kolam ikan lele terhenti. Effendi et al. (2015) menggunakan ikan lele dalam budidaya akuaponik dengan komoditas tanaman kangkung dan pakcoy. Zidni et al. (2019) juga mempelajari pengaruh sistem akuaponik dengan jenis tanaman yang berbeda terhadap kualitas air media budidaya ikan lele sangkuriang.

Kualitas air penting pada budidaya vertiminaponik, di antara terdiri dari suhu, $\mathrm{pH}$, oksigen terlarut, amonia, nitrit dan nitrat (Darwis et al. 2019), phospat, dan jenis plankton (Samsundari dan Wirawan 2013). Salah satunya parameter yang berpegaruh terhadap kualitas air adalah kadar amonia. Limbah amonia yang berasal dari sisa metabolisme ikan berupa feses dan sisa makanan ikan yang tidak termakan dan mengendap di dasar kolam budidaya dapat berdampak negatif bagi ikan (Dauhan et al. 2014). Amonia dalam bentuk $\mathrm{NH}_{3}$ tidak bermuatan dan larut dalam lemak sehingga lebih mudah terserap dalam tubuh ikan dan menggganggu metabolisme (Wahyuningsih dan Gitarama 2020).

Tanaman dalam budidaya sistem akuaponik dapat berfungsi untuk memperbaiki kualitas air yaitu dengan menurunkan konsentrasi nitrogen anorganik seperti amonia (NH3), nitrit (NO2) dan nitrat (NO3) (Damanik et al. 2018). Proses biofilter yang dilakukan oleh unit tanaman ini juga akan meningkatkan kondisi kualitas air lainnya seperti oksigen dan menurunkan kekeruhan, manfaat yang lainnya nitrogen yang dihasilkan dari pakan ikan akan memberikan massa basah besar bagi tanaman sayuran (Anderson et 
al. 2019). Kangkung darat dapat menjadi salah satu tanaman yang mengkonversi ammonium dan nitrat nitrogen dari sistem akuakultur (Sumoharjo et al. 2013). Persentasi penurunan amonium dalam air pada perlakuan kangkung adalah sebesar $78,42 \%$, hal ini terjadi karena penyerapan amonium secara langsung melalui akar sebagai pupuk alami pada kangkung lebih optimal (Efendi et al. 2015).

Biofiltrasi menggunakan tanaman juga diterapkan pada budidaya vertiminaponik. Air dari kolam ikan langsung dialirkan di talang-talang tanaman untuk disaring dan dibersihkan zat-zat toksiknya. Air yang sudah bersih dikembalikan lagi ke kolam ikan. Komoditas kangkung dipilih untuk ditanam pada vertiminaponik dengan pertimbangan umur panen yang singkat dan produksi yang tinggi. Namun penelitian tentang pengukuran reduksi amonia oleh tanaman kangkung pada teknologi vertiminaponik belum pernah dilakukan. Penelitian ini bertujuan untuk mengetahui kemampuan tanaman kangkung dalam mereduksi kandungan amonia pada teknologi vertiminaponik.

\section{BAHAN DAN METODE}

Penelitian reduksi amonia oleh kangkung darat pada budidaya vertiminaponik ini dilaksanakan di Balai Pengkajian Teknologi Pertanian DKI Jakarta pada bulan Februari - Maret 2017. Lokasi penelitian berada pada ketinggian tempat $\pm 49.8 \mathrm{~m} \mathrm{dpl}$ dengan $-6^{0} 17^{\prime} 10,444$ LS dan $106^{0} 50^{\prime} 5.351$ BT.

Bahan yang digunakan dalam penelitian ini adalah unit vertiminaponik yang terdiri dari tandon sebagai kolam penampung air, talang air untuk menanam, meja dari besi untuk meletakkan talang air, pompa air, pipa, filter air, zeolit dan kompos sebagai media tanam, kain kasa, benih kangkung (Ipomea reptans), ikan lele (Clarias sp),pakan ikan, contoh air inlet-outlet, akuades, larutan nessler, dan larutan standar amonia $(0.1 ; 0.2 ; 0.3 ; 0.4$; $0.5 \mathrm{ppm})$. Alat yang digunakan adalah alat-alat untuk berbudi daya tanaman, $\mathrm{pH}$ meter, spektrofotometer, termometer, wadah air, neraca digital, tanung reaksi, gelas ukur, pipet tetes, kertas saring 125 $\mathrm{mm}$, pipet tetes, kertas saring $125 \mathrm{~mm}$, corong dan cuvet.

Perangkat vertiminaponik terdiri dari dua bagian utama yaitu kolam pemeliharaan ikan menggunakan tangki air yang berbahan fiberglass atau tandon air (torn). Apabila menggunakan tandon air, maka dibuang bagian atasnya agar tebuka dan memiliki tinggi $80 \mathrm{~cm}$. Tempat budidaya tanaman dapat menggunakan talang plastik yang akan disusun di atas tandon kolam pemeliharaan ikan. Talang plastik ini disusun di atas rak besi sebagai penyangga. Air dari kolam pemeliharaan ikan akan disalurkan sebagai input (inlet) tanaman menggunakan pompa air yang diletakkan di dasar kolam serta dihubungkan dengan pipa paralon $3 / 4$ inci. Pipa dari pompa dihubungkan ke setiap pangkal sistem tanaman. Pengaturan besar kecilnya input air menggunakan kran. Sedangkan sistem output (outlet) air disalurkan kembali ke kolam ikan menggunakan pipa yang dihubungkan pada ujung dasar rak penanaman yang sudah dilubangi.

Rancangan percobaan yang digunakan adalah rancangan acak lengkap dengan tiga ulangan. Tanaman kangkung ditanam menggunakan media campuran zeolit dan kompos. Sebagai pembanding adalah talang kosong yang tidak ditanami. Peubah yang diamati adalah amonia inlet, amonia outlet, reduksi amonia, $\mathrm{pH}$ dan suhu air, tinggi tanaman, Data dianalisis menggunakan sidik ragam dan dilanjutkan dengan LSD jika terdapat perpedaan.

\section{HASIL DAN PEMBAHASAN Kondisi umum}

Data iklim menunjukkan saat penelitian ini dilaksanakan pada bulan 
Februari - Maret pada musim hujan, sehingga intensitas air hujan cukup tinggi di wilayah Jakarta Selatan. Secara tidak langsung, air hujan akan menambah volume air pada kolam ikan. Penambahan air pada kolam ikan hanya dilakukan pada saat volume air berkurang hingga mencapai setengah dari tandon. Penggunaan media tanam yang berasal dari campuran zeolit dan kompos mampu meloloskan air hujan dengan baik, sehingga media tanam tidak banyak menyimpan air. Tanaman kangkung termasuk jenis komoditas yang mudah dibudidayakan dan tidak terpengaruh dengan curah hujan, namun kebutuhan airnya harus tercukupi.

Talang yang ditanami kangkung menunjukkan perbedaan dengan talang yang tidak ditanami kangkung. Meskipun nilai amonia inlet yang diambil dari saluran air input memperlihatkan kadar amonia memiliki nilai yang hampir sama pada setiap talang. Namun kadar amonia outlet menunjukkan nilai yang berbeda antara talang yang ditanami kangkung dengan talang yang tidak ditanami.

\section{Kadar amonia (inlet, outlet dan reduksi amonia)}

Pengukuran kadar amonia inlet merupakan air yang berasal dari kolam ikan yang dialirkan ke wadah tanaman. Analisis secara statistik pada nilai rata-rata hasil pengamatan kadar amonia inlet menunjukkan tidak berbeda nyata pada semua talang yang berisi tanaman kangkung (Tabel 1). Rata-rata kadar amonia yang berasal dari kolam ikan memiliki nilai yang hampir sama pada setiap talang yaitu antara $0.1637-0.1657$ mg/l. Nilai kadar amonia inlet ini menunjukkan kadar amonia yang terdapat dalam kolam ikan. Primaningtyas et al.(2015) meneliti kadar amonia yang terdapat pada budidaya lele sistem resirkulasi, hasilnya menunjukkan nilai kadar amonia ialah $0.2 \pm 0.645 \mathrm{mg} / \mathrm{l}$. Chen et al. (2006) menjelaskan kadar amonia yang dapat bersifat racun bagi budidaya ikan yaitu pada konsentrasi diatas 1.5 $\mathrm{mg} / \mathrm{l}$, bahkan dalam kondisi ekstrim konsentrasi yang dapat diterima hanya $0.025 \mathrm{mg} / 1$.

Nilai kadar amonia dalam kolam teknologi vertiminaponik masih berada pada kisaran yang aman bagi pertumbuhan dan perkembangan ikan lele. Hal ini terjadi karena diduga proses reduksi amonia yang dilakukan oleh bakteri nitrosomonas dan nitrobacter berjalan dengan baik. Teknologi vertiminaponik termasuk model akuaponik yang menggunakan konsep resirkulasi. Wahyuningsih dan Gitarama (2020) dalam reviewnya menyatakan proses nitrifikasi didalam kolam ikan membutuhkan cukup oksigen dan alkalitas. Sehingga penggunaan pompa air sebagai pensuplai oksigen dan mensirkulasi air sangat membantu proses ini. Selain proses nitrifikasi didalam kolam ikan yang dilakukan oleh nitrosomonas dan nitrobacter, reduksi amonia pada vertiminaponik dibantu oleh tanaman.

Kadar amonia outlet dianalisis dengan cara mengambil air dari pipa-pipa yang keluar dibawah talang tanaman. Hasil analisis statistik terhadap nilai rata-rata kadar amonia outlet pada teknologi vertiminaponik menunjukkan berbeda nyata antara talang (Tabel 1). Talang kosong tanpa tanaman menghasilkan nilai kadar amonia outlet yang tertinggi dibandingkan dengan talang yang ditanami dengan tanaman kangkung yaitu 0.1640 $\mathrm{ml} / \mathrm{l}$. tanpa adanya tanaman menghasilkan pengurangan amonia yang paling kecil. Diduga air yang keluar dari talang ini sudah mengalami reduksi amonia yang dilakukan oleh tanaman kangkung. 
Tabel 1. Kadar amonia inlet dan outlet pada budidaya ikan menggunakan teknologi vertiminaponik

\begin{tabular}{lll}
\hline Perlakuan & Amonia inlet $(\mathrm{mg} / \mathrm{l})$ & Amonia Outlet $(\mathrm{mg} / \mathrm{l})$ \\
\hline Talang 1 & $0.1650 \pm 0.006$ & $0.1507 \pm 0.003 \mathrm{c}$ \\
Talang 2 & $0.1657 \pm 0.007$ & $0.1537 \pm 0.004 \mathrm{bc}$ \\
Talang 3 & $0.1637 \pm 0.006$ & $0.1553 \pm 0.004 \mathrm{~b}$ \\
Talang 4 & $0.1653 \pm 0.005$ & $0.1640 \pm 0.005 \mathrm{a}$ \\
\hline Pr $(>\mathrm{F})$ & 0.48 & 0.0019 \\
\hline KK $(\%)$ & 0.95 & 1.47 \\
\hline
\end{tabular}

Keterangan : Angka yang diikuti oleh huruf yang sama pada kolom yang sama menunjukkan tidak berbeda nyata menurut uji LSD pada taraf $\alpha=5 \%$, Nilai rataan diikuti oleh nilai standard error (SE)

Gambar 1 menunjukkan grafik nilai reduksi amonia yang diperoleh dari hasil analisis statistik berbeda nyata. Talang yang tidak ditanami kangkung menghasilkan nilai reduksi yang paling kecil dibandingkan dengan talang dengan tanaman kangkung. Diduga tanaman kangkung mampu melakukan reduksi amonia pada air yang berasal dari kolam ikan lele. hal ini berkorelasi dengan nilai kadar amonia outlet yang memperlihatkan nilai terkecil untuk talang tanpa tanaman kangkung. Akar tanaman mampu menyerap amonia di air yang berasal dari kolam budidaya ikan, kemudian akan dirubah menjadi nitrat setelah mengalami proses oksidasi dengan bantuan oksigen dan bakteri (Widyastuti 2008; Rahayu 2019). Damanik et al. (2018) dalam hasil penelitianya menyebutkan bahwa tanaman kangkung memiliki efektifitas rata-rata penyerapan amonia lebih tinggi 23,12\% daripada tanaman pakcoy, selada dan bayam merah.

Penelitian ini hanya menganalisis kadar total amonia yang terdapat pada air hasil budidaya ikan dan air sisa penggunaan tanaman kangkung. Total amonia ini mengandung NH3 (amonia bebas), $\mathrm{NH} 4+$ (amonium) dan NO3 (nitrat) (Rahmawana et al. 2019). Penelitian efektifitas penggunaan tanaman kangkung pada penurunan kadar total amonia dan nitrogen sudah dilakukan oleh Efendi et al. (2015), hasilnya menyebutkan bahwa perlakuan menurunkan amonium sebesar
$78.42 \%$, amonia bebas menurun sebanyak $93.62 \%$. selain itu juga terbukti penyerapan amonium secara langsung melalui akar sebagai pupuk alami pada kangkung lebih optimal dan lebih efektif dalam meningkatkan tingkat kelangsungan hidup dan laju konversi pakan ikan lele.

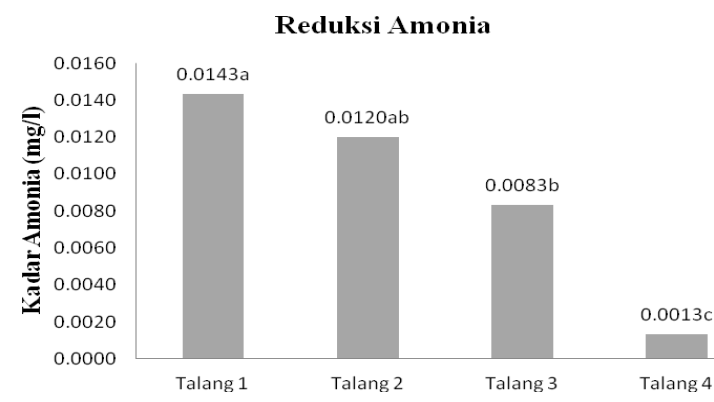

Keterangan :

Angka yang diikuti oleh huruf yang sama pada grafik menunjukkan tidak berbeda nyata menurut uji LSD pada taraf $\alpha=5 \%$

Gambar 1. Grafik reduksi amonia oleh tanaman kangkung pada teknologi vertiminaponik

\section{pH dan suhu air}

Kandungan $\mathrm{pH}$ air dari kolam ikan selain berpengaruh terhadap pertumbuhan dan perkembangan ikan lele, juga berpengaruh terhadap permbuhan tanaman kangkung. Intensitas curah hujan juga dapat menyebabkan perubahan yang cukup besar terhadap lingkungan perairan, seperti suhu air dan fluktuasi pH. Hasil pengamatan harian bak penampung ikan lele menunjukkan $\mathrm{pH}$ rata-rata pada kolam 
ikan antara 7.2 - 7.9 (Gambar 2). Lestari (2013) menjelaskan bahwa $\mathrm{pH}$ yang sesuai untuk pertumbuhan tanaman berkisar antara 5.0-7, jika terlalu rendah $(<4.5)$ atau terlalu tinggi $(>7.0)$ dapat menghambat pertumbuhan suatu tanaman. Wedemeyer (1996) menyebutkan bahwa nilai $\mathrm{pH}$ yang baik bagi budidaya ikan berada pada rentang 6.5 sampai 9.

$\mathrm{pH}$ yang dihasilkan pada kolam ikan masih berada pada kisaran $\mathrm{pH}$ yang baik untuk budidaya ikan, namun terlalu tinggi untuk pertumbuhan tanaman kangkung. Hasil penelitian Efendi et al. (2015) menyebutkan hasil pengukuran $\mathrm{pH}$ kolam ikan lele antara 6-8. Sedangkan penelitian Damanik et al. (2018) menghasilkan pH pada kolam ikan antara $6.8-7.5$. Kondisi $\mathrm{pH}$ air di kolam budidaya ikan akan berpengaruh juga terhadap proses dekomposisi senyawa organik. Meningkatnya $\mathrm{pH}$ pada kolam ikan akan meningkatkan konsentrasi amonia (Dauhan et al. 2014). Keuntungan penggunaan resirkulasi adalah pergerakan aliran air ke dalam reaktor dapat membuat $\mathrm{pH}$ air berkurang, sehingga proses nitrifikasi berlangsung lebih cepat dengan bertambahnya aliran air ke dalam reaktor (Leonanda dan Zolanda 2018).

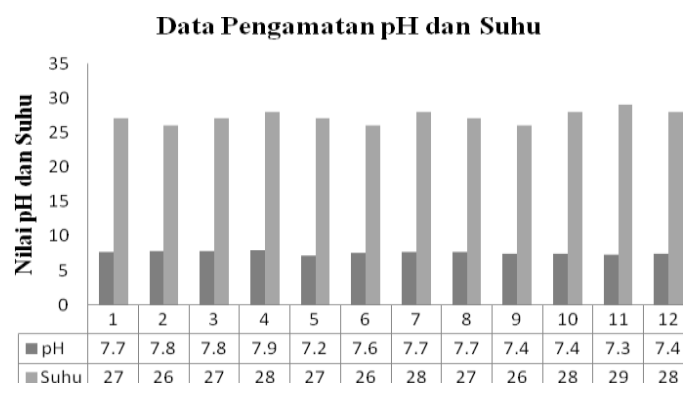

Gambar 2. Grafik data pengamatan $\mathrm{pH}$ dan suhu harian bak ikan pada teknologi vertiminaponik

\footnotetext{
Sistem resirkulasi dalam budidaya ikan menggunakan teknologi vertiminaponik akan berpengaruh terhadap suhu harian dalam kolam penampung ikan lele. Hasil pengamatan suhu air pada kolam
}

ikan antara $26-29{ }^{0}$ C. Suhu air yang dimiliki oleh kolam ikan vertiminaponik masih tergolong sesuai untuk budidaya ikan dan pertumbuhan tanaman kangkung. Byod dan Lichtkoppler (1982) menjelaskan bahwa ikan paling baik hidup pada kisaran suhu $25-32{ }^{0} \mathrm{C}$. Lestari (2013) menyatakan bahwa suhu yang optimum untuk pertumbuhan kangkung berkisar antara $25-30 \quad{ }^{0} \mathrm{C}$. Hasil pengamatan model akuaponik ikan lele dan tanaman kangkung yang diujicobakan oleh Efendi et al. (2015) menghasilkan suhu harian rata-rata $27-30{ }^{0} \mathrm{C}$. Perangkat akuaponik yang diteliti oleh Damanik et al.(2018) untuk budidaya lele dan tanaman kangkung memiliki suhu rata-rata harian antara $24.5-28.2{ }^{\circ} \mathrm{C}$.

Suhu air pada kolam ikan selain berpengaruh pada pertumbuhan ikan lele dan tanaman, juga dapat berpengaruh terhadap proses dekomposisi senyawa organik. Jika proses dekomposisi senyawa organik dalam kolam tidak terjadi dengan baik, maka akan terbentuk senyawa amonia yang melebihi ambang batas. Hal ini akan menyebabkan munculnya bau tidak sedap dari dalam kolam ikan. Samsumdari dan Wirawan (2013) menyimpulkan bahwa suhu mempengaruhi kelarutan oksigen di dalam air serta menyebabkan interaksi berbagai faktor lain dalam parameter kualitas air. Kenaikan suhu dan $\mathrm{pH}$ juga akan meningkatkan konsentrasi amonia dalam kolam penampung ikan (Dauhan et al. (2014). Lebih lanjut Putra et al.(2016) menambahkan bahwa suhu yang rendah dalam kolam juga dapat mengakibatkan proses nitrifikasi terhambat dan mengakibatkan amoniak menjadi tinggi. Nilai Suhu yang rendah secara langsung mempengaruhi nilai oksigen terlarut yang sering menjadi faktor pembatas untuk kegiatan budidaya (Damanik et al. 2018). Suhu optimal yang dikehendaki bakteri agar dapat beraktivitas dan berkembang biak dengan baik berada pada kisaran suhu $25-29{ }^{0} \mathrm{C}$ (Taufik et al. 2005). 


\section{Tinggi Tanaman}

Tanaman kangkung pada budidaya akuaponik menggunakan teknologi vertiminaponik dapat tumbuh dan berkembang dengan baik. Kangkung merupakan salah satu komoditas tanaman yang memiliki umur panen pendek, biasanya dipanen pada umur 21-25 hari setelah tanam. Pengamatan tinggi tanaman dilakukan sebanyak empat kali, setiap empat hari sekali. Hasil analisis statistik pada data rata-rata pengamatan menunjukkan terdapat perbedaan nyata antar perlakuan talang pada pengamatan kedua (Tabel 2). Pengamatan ke tiga dan ke empat, talang yang ditanami kangkung menunjukkan tidak berbeda nyata.

Kondisi kadar amonia, $\mathrm{pH}$ yang cenderung basa dan suhu yang cukup memadai tanaman kangkung pada vertiminaponik ini dapat tumbuh dengan normal seperti pada kondisi media tanam tanah dan penambahan pupuk. Memasuki pekan ke 3 setelah tanam, tinggi tanaman kangkung antara $16.54-17.17 \mathrm{~cm}$. Hal ini sesuai dengan hasil penelitian Irawati dan Salamah (2013) yang menyebutkan tinggi tanaman kangkung pekan ke 3 setelah tanam antara $14.02-18.46 \mathrm{~cm}$.

Tabel 2. Pertumbuhan tanaman kangkung pada budidaya vertiminaponik

\begin{tabular}{lllll}
\hline \multirow{2}{*}{ Perlakuan } & \multicolumn{4}{c}{ Tinggi Tanaman Pengamatan ke - } \\
\cline { 2 - 5 } & \multicolumn{1}{c}{1} & \multicolumn{4}{c}{3} & 4 \\
\hline Talang 1 & $2.39 \pm 0.03 \mathrm{a}$ & $4.75 \pm 0.16 \mathrm{a}$ & $10.10 \pm 0.25 \mathrm{a}$ & $17.17 \pm 0.30 \mathrm{a}$ \\
Talang 2 & $2.49 \pm 0.06 \mathrm{a}$ & $4.58 \pm 0.05 \mathrm{ab}$ & $9.77 \pm 0.27 \mathrm{a}$ & $17.12 \pm 0.53 \mathrm{a}$ \\
Talang 3 & $2.45 \pm 0.02 \mathrm{a}$ & $4.34 \pm 0.10 \mathrm{~b}$ & $4.34 \pm 0.10 \mathrm{a}$ & $16.54 \pm 0.49 \mathrm{a}$ \\
Talang 4 & $0.00 \pm 0.00 \mathrm{~b}$ & $0.00 \pm 0.00 \mathrm{c}$ & $0.00 \pm 0.00 \mathrm{~b}$ & $0.00 \pm 0.00 \mathrm{~b}$ \\
\hline Pr $(>\mathrm{F})$ & 0.00 & 0.00 & 0.00 & 0.00 \\
\hline KK $(\%)$ & 3.31 & 5.77 & 5.40 & 5.94 \\
\hline
\end{tabular}

Keterangan :

Angka yang diikuti oleh huruf yang sama pada kolom yang sama menunjukkan tidak berbeda nyata menurut uji LSD pada taraf $\alpha=5 \%$, Nilai rataan diikuti oleh nilai standard error (SE)

Tanaman kangkung dapat merubah amonia yang diserap pada daerah perakaran menjadi senyawa nitrat yang dapat dimanfaatkan untuk proses metabolisme. Dauhan et al (2014) pada hasil penelitiannya menyebutkan penyerapan terhadap amonia sangat optimal dimanfaatkan oleh tanaman kangkung untuk pertumbuhannya. Penyerapan amonia dari air kolam ikan oleh tanaman kangkung dapat diketahui dengan menganalisis proksimat peubah tingkat retensi nitrogen dan total produksi amonia. Hasil analisis proksimat tanaman kangkung yang dilakukan oleh Sumoharjo et al. (2013) menunjukkan bahwa tingkat retensi nitrogen yang dicapai sebesar $0.73 \pm 0.28 \mathrm{~g}$, terjadinya proses konversi nitrogen dari air ke biomassa tanaman yang dibuktikan dengan adanya kenaikan TKN (total Kjedahl nitrogen) hingga $23.80 \pm 5.95 \%$, efisiensi penyisihan TAN (total amonia dan nitrogen) dari kolam ikan oleh tanaman ditunjukkan dengan penyerapan $6.70 \%$ TAN dari total produksi amonia ikan dengan rata-rata tanaman kangkung adalah $1,14 \pm 0,43 \% \mathrm{~N}$ lebih tinggi dibandingkan dengan kemangi dan sawi.

\section{KESIMPULAN}

Tanaman kangkung pada budidaya akuponik menggunakan teknologi vetiminaponik mampu mereduksi kadar amonia yang dihasilkan oleh kotoran dan sisa pakan ikan. Kadar amonia outlet dan reduksi terendah dimiliki oleh talang yang tidak ditanami kangkung. $\mathrm{pH}$ rata-rata pada 
kolam ikan antara $7.2-7.9$ masih sesuai untuk budidaya ikan, namun kurang baik untuk pertumbuhan tanaman kangkung. Suhu air pada kolam ikan antara $26-29{ }^{\circ} \mathrm{C}$ sesuai untuk budidaya ikan dan tanaman. Tinggi tanaman kangkung vertiminaponik sesuai standar pada budidaya menggunakan tanah, amonia yang direduksi oleh tanaman kangkung digunakan untuk tumbuh kembangnya.

\section{DAFTAR PUSTAKA}

Anderson T.S., Goldstein L.T., \&Timmons MB (2019). Root nitrification Capacity of Lettuce Plants with Application to Aquaponics. Aquacultural Engineering. 86: 1-6.

Byod C.E., \& Lichtkoppler F. (1982). Water Quality Management in Pond Fish Culture. International Center for Aquaculture. Alabama (USA). Auburn University Press.

Chen S., Ling J., \& Jean-paul B. (2006). Nitrification Kinetics of Biofilm as Affected by Water Quality Factors. Aquacultural

Engineering. 34(3):179-197.

Damanik B.H., Hamdani H., Riyantini I., \& Herawati H. (2018). Uji Efektifitas Bio Filter dengan Tanaman Air untuk Memperbaiki Kualitas Air pada Sistem Akuaponik Ikan Lele Sangkuriang (Clarias gariepinus). Jurnal Perikanan dan Kelautan. IX (1): 134-142.

Darwis, Mudeng J.D., \& Londong S.N.J. (2019). Budidaya Ikan Mas (Cyprinus carpio) Sistem Akuaponik dengan Padat Penebaran Berbeda. Budidaya Perairan. (7): 15 -21.

Dauhan R.E.S., Efendi E., \& Suparmono (2014). Efektifitas Sistem Akuaponik dalam Mereduksi
Konsentrasi Amonia pada Sistem Budidaya Ikan. e-Jurnal Rekayasa dan Teknologi Budidaya Perairan. 3(1): 297-301.

Effendi H., Utomo B.A., Darmawangsa G.M., \& Karo-Karo R.E. (2015). Fitoremediasi Limbah Budidaya Ikan Lele (Clarias sp.) dengan Kangkung (Ipomoea aquatica) dan Pakcoy (Brassica rapa chinensis) dalam Sistem Resirkulasi. Ecolab. 9(2):47-104.

Estim A., Saufie S., Mustafa S. (2019). Water Quality Remediation using Aquaponics Sub-systems as Biological and Mechanical Filters in Aquaculture. J. Water Process Eng. 30(1): doi:10.1016/j.jwpe.2018.02.001.

Irawati, \& Salamah Z. (2013). Pertumbuhan Tanaman Kangkung Darat (Ipomoea reptans Poir.) dengan Pemberian Pupuk Organik Berbahan Dasar Kotoran Kelinci. Jurnal Bioeduka Tika. 1(1): 91-96.

Leonanda B.D., \& Zolanda Y. (2018). Reaktor Nitrifikasi Biofilter untuk Air Limbah Sisa Makanan dan Feses Ikan. Metal : Jurnal Sistem Mekanik dan Termal. 2(1): 9-14.

Lestari W. (2013). Penggunaan Ipomoea aquatica Forsk. untuk Fitoremediasi Limbah Rumah Tangga. Prosiding Semirata FMIPA Universitas Lampung. 441 - 446.

Primaningtyas A.W., Hastuti S., \& Subandiyono (2015). Performa Produksi Ikan Lele (Clarias gariepinus) yang Dipelihara dalam Sistem Budidaya Berbeda. Journal of Aquaculture Management and Technology. 4(4): 51-60. 
Putra S., Arianto A., Efendi E., Hasani Q., \& Yulianto H. (2016). Efektifitas Kijing Air Tawar ( Pilsbryoconcha exilis ) sebagai Bio Filter dalam Sistem Resirkulasi terhadap Laju Penyerapan Amoniak dan Pertumbuhan Ikan Lele Sangkuriang (Clarias gariepinus). e-Jurnal Rekayasa dan Teknologi Budidaya Perairan. 4(2): 497 - 506.

Rahayu N.C.P. (2019). Perbedaan Tanaman Buah Tomat (Lycopersiconesculentum), Cabai (Capsisumfrutencens), dan Terong (Solanum melongena L.) pada Penyerapan Amonia (NH3) dan Nitrat (NO3) Air Budidaya Ikan Lele Dumbo (Clarias sp) pada Sistem Akuaponik (Skripsi). Surabaya (ID): Universitas Airlangga.

Rahmawana A.J., Effendi H., \& Suprihatin (2019). Potensi Rumput Vetiver (Chrysopongon zizanoides L.) dan Kangkung (Ipomoea aquatica Forsk.) sebagai Agen Fitoremediasi Limbah Industri Kayu. Journal of Natural Resources and Environmental Management. 9(4): 904-919.

http://dx.doi.org/10.29244/jps1.9.4.9 04-919.

Rokhmah N.A., Amatillah C.S., \& Sastro Y. (2014). Vertimaponik, Mini Akuaponik untuk Lahan Sempit di Perkotaan. Buletin Pertanian Perkotaan. 4(2): 14-22.

Samsundari S., \& Wirawan G.A. (2013). Analisis Penerapan Biofilter dalam Sistem Resirkulasi terhadap Mutu Kualitas Air Budidaya Ikan Sidat (Anguilla bicolor). J. Gamma. 8(2):86-97.
Sumoharjo, Maidie A,. Saleha Q., Erwiantono, \& Fahlefi E.N. (2013). Penyisihan Limbah Nitrogen dari Sistem Akuakultur Multitrofik Terpadu Menggunakan Tanaman Sayur sebagai Konverter Fotoautotrof. J. Ris. Akuakultur. 8(3): 393-401.

Taufik I., Sutrisno, Yuliati P., Supriyadi H.B., Subandiyah S., \& Muthalib I. (2005). Studi Pengaruh Suhu Air terhadap Aktivitas Bakteri Bioredemias (Nirtosomonas dan Nitrobacter) pada Pemeliharaan Benih Ikan Patin Siam (Pangasius hypopthalmus). Jurnal Penelitian Perikanan Indonesia. 11(7): 60-66.

Wahyuningsih S., \& Gitarama A.M. (2020). Amonia pada Sistem Budidaya Ikan. Syntax Literate : Jurnal Ilmiah Indonesia. 5(2): 112 125.

Wedemeyer G.A. (1996). Physiology of Fish in Intensive Culture Systems. New York (USA). International Thompson Publishing.

Widyastuti Y.R. (2008). Peningkatan Produski Air Tawar melalui Budidaya Ikan Sistem Akuaponik. Bogro : Prosiding Seminar Nasional Limnologi IV LIPI. 62 - 73.

Zidni I., Iskandar, Rizal A., Andriani Y., \& Ramadan R.( 2019). Efektifitas Sistem Akuaponik dengan Jenis Tanaman yang Berbeda terhadap Kualitas Air Media Budidaya Ikan. Jurnal Perikanan dan Kelautan. 9(1):81-94. 